\title{
Erratum to: World Map of Scientific Misconduct
}

\author{
Behzad Ataie-Ashtiani ${ }^{1,2}$
}

\section{Erratum to: Sci Eng Ethics \\ DOI 10.1007/s11948-017-9939-6}

The original version of this article was revised: Reference 'Qiu, J. (2010). China drought highlights future climate threats. Nature, 463(7278), 142-143.' has been replaced by 'Qui, J. (2010). Publish or perish in China. Nature, 463(7278), 142-143.'

The online version of the original article can be found under doi:10.1007/s11948-017-9939-6.

Behzad Ataie-Ashtiani ataie@sharif.ir

1 Department of Civil Engineering, Sharif University of Technology, PO Box 11155-9313, Tehran, Iran

2 National Centre for Groundwater Research and Training and School of the Environment, Flinders University, GPO Box 2100, Adelaide, SA 5001, Australia 